\title{
Sulconazole Nitrate
}

National Cancer Institute

\section{Source}

National Cancer Institute. Sulconazole Nitrate. NCI Thesaurus. Code C47733.

The nitrate salt form of sulconazole, a synthetic imidazole derivative with antifungal property. Sulconazole nitrate inhibits fungal cytochrome P-450 sterol C-14 alphademethylation, resulting in the accumulation of fungal 14 alpha-methyl sterols and inhibition of the synthesis of ergosterol, an important component of the fungal cell membrane. Inhibition of ergosterol synthesis leads to a disruption of cell membrane permeability, and ultimately inhibition of cell wall synthesis. In addition, sulconazole nitrate seems to interfere with the autolytic degradation of fungal DNA and RNA. 